\title{
The Effect of Gamification Activities on Students' Academic Achievements in Social Studies Course, Attitudes towards the Course and Cooperative Learning Skills \\ Çilem ÖZTÜRK \\ Amasya University, Institute of Sciences, The Department of Computer Education and Instructional Technologies, ORCID: /0000-0002-4726-7453
}

\section{Özgen KORKMAZ*}

Amasya University, The Faculty of Technology, The Department of Computer Engineering, Amasya, ORCID: 0000-0003-4359-5692

Article history

Received:

17.09.2019

Received in revised form: 03.12.2019

Accepted:

04.12.2019

Key words:

Gamification, social studies teaching, cooperative learning, attitude, playing game

The aim of this study is to determine the effects of educational games on students' academic achievement, attitudes towards the course and cooperative learning skills. Semi-experimental research design with pretest posttest control group was used. The study group consisted of 60 students at 5th grade secondary school. In this process, the topics identified were reinforced by educational games in experimental group and control group were strengthened by traditional methods for 6 weeks. Research data were collected by using Social Studies Course Attitude Scale (Cronbach Alpha $=0.61)$, Cooperative Learning Scale $(\alpha=0.80)$ and Social Studies Course Academic Achievement Scale (kr-20=0.78). The mean, standard deviation, and Anova analyses were performed As a result: Social Studies Education reinforced by gamification contributes significantly more to students ' attitudes towards social studies course than traditional method. However, it was determined that it did not contribute significantly to the benefit factor. Social studies education, which is reinforced by educational games, contributes significantly more to students ' cooperative learning skills than the traditional method. Social studies education, which is reinforced by educational games, contributes significantly more to students ' academic achievement towards social studies course than the traditional method.

\section{Introduction}

Social studies course, both at individual and societal level, aims at raising active and productive citizens who are aware of their rights and fulfill their responsibilities. Among the values stated in the Instructional Program of Social Sciences developed by the Ministry of National Education (MONE), cooperation, responsibility and patriotism are in the spotlight (MONE, 2018). According to Poyrazoğlu (1987), the function of social studies course is to introduce the issues regarding individual and society and teach the ability to find ways to solve these issues. Along with this, social studies course enables students to learn and internalize national and spiritual values as well as adopting a democratic attitude towards universal values. Among the specific values of MONE's instructional programme of social 
studies, the first one is "to educate students to be citizens who love their homeland and nation, know their rights and apply them, fulfill the duties and responsibilities that they have and have national consciousness as a citizen of Turkish Republic" (MONE, 2018). In the studies done related to the instruction of social studies course, it is stated that especially while designing the content of social studies for secondary schools, the readiness level of the students does not seem to be considered, which causes issues in teaching the course (Acar, 2003). In a quantitative study conducted by Arslantaş (2006) about the instruction of social studies, teachers pointed out that the current curriculum in practice is too comprehensive, the content carries abstraction and fails to draw the attention of the students. In response to these issues regarding the content and instruction of social studies course, the literature underlines the need to develop an understanding of social studies instruction based on the constructivist learning theory. According to Chen (2003), constructivist learning theory is a contemporary approach whose ultimate aim is to ensure that individuals are active participants during the learning and teaching process by putting the individuals who are learning, that is learners, at the center of the teaching and learning process in all courses. Various methods are being used in the instruction of social studies. However, rather than such teacher-centered methods as lecturing, it is emphasized that learner based methods like discussion, drama, question and answer, problem solution, project, research, field trip observation and gamification are more likely to contribute to the learners. (Alkan \& Kurt, 1998; Sönmez,1996; Kısakürek, 1988; Binbaşıoğlu, 1981).

Games can enable a child to build relationships with the environment, express emotions, gain experiences, have a good time, relax and find solutions to the problems. (Bayram at. Al., 1999). Muntean (2011) emphasizes that learners display a positive attitude towards gamification and gamification fosters learner motivation and generally helps learners receive positive feedback during teaching process. In a study carried out by Polat (2014), Gibson and his colleagues (2015), it is stated that games lead learners to display positive attitude and have positive influences over success. It is also highlighted that games have always been a tool that draws the attention of many people (Sar1 and Altun, 2016). It is stated that activities that involve games contribute to communication skills as well as muscle coordination (Jones, 2001).

Prensky (2002) emphasizes the need to eliminate the factors causing learning difficulties in learning environments and make learning enjoyable. In this sense, conducting courses with educational games, or learning through entertainment is likely to be effective in students' learning. Educational games lead to the active participation of students, especially shy ones and this has a direct influence over the student's interest and attitude towards a course (Bayat, Kılıçarslan \& Şentürk, 2014). This process called active participation presents the opportunity for the students to express their ideas and feelings and increases their creativity (Uberman, 1998). The positive effect of the environments enriched by games has been supported by other studies (Aycan at. al. 2002; Karamustafaoğlu \& Kaya, 2013). Similar studies done by Saracaloğlu and Aldan Karademir (2009), Uzun (2012) and Yurt (2007) show that games promote success and make it easier and more entertaining to reach course objectives.

In the literature, along with the notion of educational game, the concept of gamification is also frequently encountered. Gamification is an entertaining instructional method that allows for repetition in an environment which is fun to be for the students (Bayat, Kilıçaslan \& Şentürk, 2014; Güler, 2011). It is indicated that the most prominent feature of gamification is to enable abstract experiences to be transformed into concrete ones, which can build a bridge between theoretical learning and applications (Varışoğlu at al., 2013; Öztemiz \& Önal, 2013). 
Likewise, Canbay (2012) stated that gamification offers students opportunities for cooperation, competition and active participation in learning process. However, like other teaching methods, gamification might also have some limitations. In the studies done related to this, it is indicated that slow learners may be negatively affected in the competitive environments (Coşkun, 2012). Another limitation is that the games that do not match with learning objectives may fail to help students to achieve learning objectives (Ülküdür, 2016). Considering all these limitations, it would be fair to say that an effective gamification needs to be designed by considering the limitations and in line with student needs, learning objectives, class atmosphere. Karaaslan (2013) and Prensky (2001) came up with a comprehensive definition and stated that games are comprised of twelve elements. These twelve elements suggest that games:

(1) are enjoyable and entertaining,

(2) are attractive and they enable students to be passionately attached

(3) involve rules as the foundation of the games

(4) foster motivation

(5) are interactive and facilitate the active participation of the students

(6) can be adapted in terms of challenge level depending on the performance of the player

creating a bond between the game and the player

1) have results and feedback through which players have the chance to learn

2) creates opportunities for the player to win and satisfy his/her ego

3) involve the features of struggle, competition, challenge and rivalry, all of which make the games exciting

4) involve problematic situations that need to be solved and this kind of situations help the students to develop their individual thinking skills

5) allows for interaction among the players and this contributes to the construction of social groups

6) present stories and players experience the feelings in the story as part of the story itself

In addition to this, Prensky recognized six of these twelve elements as the elements which render games entertaining and the other six as the elements which constitute the basic structural features of the games. According to Prensky (2001), the basic structural features of games are outlined as rules (Kramer, 2000; Kula \& Erdem, 2005; Prensky, 2001; Maroney, 2001), aims and objectives, output and feedback, conflict/competition/challenge/rivalry, interaction and story.

On the other hand, considering that educational games are actually group activities, they are believed to foster the students' ability to work cooperatively. Cooperative learning can be defined as students' achieving the common objectives by helping each other in small groups to learn (Hazne \& Berger, 2007; Hennessy \& Evans 2006). In this way, the students who belong to a certain group will grasp the importance of cooperation. Another definition of cooperative learning is "a learning approach in which students work in the class within small heterogenous groups to achieve a common objective by helping each other learn and consolidate group success in different ways" (Açıkgöz, 2000). It is also believed that cooperative learning activities can facilitate the ability to acquire knowledge and produce (Brufee, 1993). Tannenberg (1995) describes the benefit of cooperative learning as "the most important contribution of cooperative learning that I noticed while implementing this approach is that cooperative learning provides exercises for the students to improve their 
skills with the discipline necessary for a competition". Besides, Tannenberg (1995) stated that exercises involve activities such as reading, designing, understanding programs, writing evidence, teaching to another student.

In the literature, it is possible to encounter evidence suggesting that gamification has an influence over numerous psychometric variables such as academic success, attitude and motivation (Bayat, Kilıçarslan \& Şentürk, 2014; Coşkun, Kariper, \& Akarsu, 2012; Demir, 2012). However, the literature does not include enough evidence as to the effectiveness of games and gamification, especially in social studies course. On the other hand, this study put forward the effect of gamification method over the attitude towards the course and cooperation as well as over success. Within this framework, it is believed that the present study can contribute to the literature.

\subsection{Problem Statement and subproblems}

What is the influence of gamification activities in social studies course over the students' academic success, attitude towards the course and cooperative learning skills?

- Does a social studies course supported by gamification activities contribute to the students' attitude towards the course?

- Does a social studies course supported by gamification activities contribute to the students' academic success?

- Does a social studies course supported by gamification activities contribute to the cooperative learning skills of the students?

\section{Method}

\subsection{Research Model}

In this study, a quasi-experimental research design with a pretest-posttest control group was employed. Quasi-experimental research design and excremental research design are similar in terms of their aims. Both aim at exploring the cause-effect relationships between the variables. In this study, control and experimental group were randomly chosen. Equality in terms of features like academic success and attitude was not considered. In the study, the independent variable is social studies course supported by gamification. Table 1 outlines the experimental model used in the study

Table 1. Experimental Design

\begin{tabular}{|c|c|c|c|}
\hline Groups & Pretest & $\begin{array}{l}\text { Experimental } \\
\text { Manipulation }\end{array}$ & Posttest \\
\hline Experimental Group & $\begin{array}{l}\text { - Academic } \\
\text { achievement test } \\
\text { - Social studies attitude } \\
\text { scale }\end{array}$ & $\begin{array}{l}\text { Social studies course } \\
\text { supported by educational } \\
\text { activities }\end{array}$ & $\begin{array}{l}\text { - Academic } \\
\text { achievement test } \\
\text { - Social studies attitude } \\
\text { scale }\end{array}$ \\
\hline Control Group & $\begin{array}{l}\text { - Cooperative learning } \\
\text { scale }\end{array}$ & Traditional method & $\begin{array}{l}\text { - Cooperative learning } \\
\text { scale }\end{array}$ \\
\hline
\end{tabular}

\subsection{Study Group}

The study group for this study is comprised of 60 students, 31 students from class 5/A and 29 students from 5/B, all of whom study at a secondary school in Ankara. For the study, the available classes were used, and no effort was made to match the groups. However, which group would be the experimental group and which would be the control was randomly 
determined. The distribution of the study group based on gender and groups is summarized in Table 2 below.

Table 2. The Distribution of the study group based on gender and groups

\begin{tabular}{llll}
\hline & Experiment & Control & Total \\
\hline Female & 13 & 14 & 27 \\
Male & 18 & 15 & 33 \\
Total & 31 & 29 & 60 \\
\hline
\end{tabular}

\section{3. Data Collection Tools}

Social Studies course attitude scale, cooperative learning attitude scale ad academic success test were used in the study as data. The details of the data collection tools are given below:

Social Studies course attitude scale: Social Studies course attitude scale developed by Gömleksiz and Kan (2013) to measure the attitude towards social studies course is comprised of 29 items and 5 factors. The factors named as "love", "benefit", "interest" and "motivation and trust" include 10, 6, 5 and 4 items respectively. The Cronbach Alpha coefficient of the total scale was calculated as 0.61 . The reliability coefficient of "Love" as the subdimension of the scale is .97 and the explained variance is 35.92. The reliability coefficient for the subdimension of "Benefit" is .88 and the explained variance is 8.94 . For the "Interest" subdimension of the study, the reliability coefficient was found to be .77 and its explained variance is 4.03 . The reliability coefficient for the subdimension of "Motivation" is .76 and the explained variance is 3.58. As for the "Trust" subdimension of the study, the reliability coefficient is .74 and this subdimension accounts for the 3.49 percent of the total variance. Guttman Split Half coefficient of the scale was specified as 0.71. Equal length and unequal length Spearman Brown coefficients were also calculated as 0.71 .

Cooperative Learning Scale: To measure the students' cooperative learning skills, the cooperative learning scale developed by EL-Deghaidy and Nouby (2008) and adapted by Kiper (2016) into Turkish was utilized. The scale is a likert-type scale with 20 items forming one factor. The structural validity of the scale was investigated through confirmatory factor analysis and it was found that fit indices were perfectly in line with each other. The internal consistency of the scale (Cronbach alpha) was calculated as 0.80 .

Social Studies Academic Achievement Test: The scale developed by the researcher is comprised of 30 multiple-choice items with four options all of which are about the unit entitled as Technology Society and Science in the 5th Grade Social Studies course. After the draft test form was developed, it was administered to 100 students apart from the experimental and control groups. Based on the pilot study conducted, $\mathrm{Kr}-20$ value was found to be 0.78 , average difficult index was calculated as 0.58 and the item discrimination values are given in Table 2. The items whose item discrimination index is below 0.30 were eliminated from the test. The item discrimination levels of the remaining items are provided in Table 3.

In the light of this, it could be claimed that the scale can measure the students' attitude towards the Technology Society and Science unit in Social Studies course with acceptable validity and reliability. 
Table 3. Item discrimination index of social studies course achievement test

\begin{tabular}{|c|c|c|c|}
\hline Item No & Item Discrimination & Item No & Item Discrimination \\
\hline M1 & 0,44 & M11 & 0,48 \\
\hline M2 & 0,55 & M12 & 0,48 \\
\hline M3 & 0,48 & M13 & 0,51 \\
\hline M4 & 0,41 & M14 & 0,63 \\
\hline M5 & 0,30 & M15 & 0,59 \\
\hline M6 & 0,30 & M16 & 0,55 \\
\hline M7 & 0,48 & M17 & 0,63 \\
\hline M8 & 0,56 & M18 & 0,37 \\
\hline M9 & 0,41 & M19 & 0,51 \\
\hline M10 & 0,33 & M20 & 0,81 \\
\hline
\end{tabular}

\subsection{Experimental Activities}

In this study, there is an experimental group and control group. Class 5/A was chosen as the experimental group and class 5/B was chosen as the control group. The length of study period was determined as 6 weeks. The activities done in these groups are as follows:

For the experimental group, in the first week the subject of 'Technology and Society', which is covered in grade 5 unit 4, was chosen. The subject chosen was covered in class 5/A, as the experimental group, through activities like lecture, use of book illustration, video display on Eba and poster preparation. In class 5/B, as the control group, the subject of 'Technology and Society' was covered through the same activities conducted in the experimental group (lecture, use of book illustration, video display on Eba about the subject and poster preparation).

In the second week, in order for the students to consolidate the subject, gamification activity was designed and implemented as a whole class. For the gamification 'I will shoot a basket and get the score', a basketball hoop was placed in the middle of the board; students were divided into two groups; groups were named by the students and group names were written on the board. Among the group competitors who started shooting a basket after the teacher blew the whistle, a question was posed to the group of the student who first scored a basket; if the student could answer the student correctly, +1 point was added to their score and new students continued competing. If not, the same question was asked to the player in the other group, if that student could give the right answer, then +1 point was added to the score of the group. After all the competitors competed, their scores were calculated and the group with the highest score won. After the gamification, the process of competition was evaluated, rules and limitations of the gamification were discussed with the students. In the control group; on the other hand, worksheets consisting of tasks like fill-in-gaps, matching and multiple-choice questions were studied so that the students could consolidate the subject.

In the third week, the subject of 'True and Reliable Information' from the same unit was chosen for the experimental group. Related to this, reading texts were studied with the students, book illustrations were investigated, and the salient points of the subject were emphasized through lecturing. The same subject was studied through similar methods and techniques like lecturing, getting the students to read texts and investigate the illustrations.

In the fourth week, gamification activity was developed and played as a whole class for the consolidation of the subject in the experimental group. For the gamification "Crazy Racket", the students were divided into two groups each of which was named by the students 
themselves. A table was placed in the middle of the class with a button on it. The competitors were provided with a tennis racket and ball. After the teacher blows the whistle, the first student who reached the button by bouncing the ball on the racket was given the right to reach the question. If the student can answer the student correctly, +1 point is added to their score. If not, the same question is asked to the player in the other group, if that student can give the right answer, then +1 point is added to the score of the group. After all the students in the groups competed, the scores of both groups were calculated and the group with the highest score won. After the gamification, with the students in the experimental group, the process of competition was evaluated, rules and limitations of the gamification were discussed along with suggestions for the future gamifications. Within the same week, in the control group, an online test was done on Morpa Campus and through the questions on the worksheets involving various tasks, consolidation was facilitated.

In the fifth week, 'Security on a Virtual Environment' was chosen for the experimental group as a subject from the same unit. Related to this subject, videos were watched on Eba and Morpa campus, the illustrations in the coursebook were investigated, the key points of the subject were highlighted. The same subject was studied through similar methods and techniques like lecturing, video display and studying the illustrations.

In the sixth week, gamification activity was developed and played as a whole class for the consolidation of the subject in the experimental group. For the gamification called 'Keep Dancing', all the papers on which questions were written were put in a box. The students in the class were gathered in a circle. The teacher played the music chosen by the students and the question box was handed around. Whoever held the box when the teacher paused the music read the question outload and if the student succeeded in giving the correct answer, s/he continued with the gamification; if not, s/he stepped out of the circle. In this way, it was made sure that every student answered at least one question and the ones who were not eliminated at the end of the gamification were considered as the winners. After the gamification finished, a discussion about the gamification was done with the students, information about the questions that the students could not answer correctly was given and ideas were exchanged. In the control group, consolidation was facilitated through worksheets involving different tasks. In Table 4, the process applied for experimental and control groups is given.

Table 4. Experimental Process

\begin{tabular}{|c|c|c|c|c|}
\hline Name of the Unit & Outcomes & Duration & $\begin{array}{l}\text { Experimental } \\
\text { Group Activities }\end{array}$ & $\begin{array}{l}\text { Control } \\
\text { Activities }\end{array}$ \\
\hline $\begin{array}{l}\text { Technology-Science- } \\
\text { Society }\end{array}$ & $\begin{array}{l}\text { The effect of technology } \\
\text { use on socialization }\end{array}$ & $\begin{array}{l}2 \text { class } \\
\text { hours }\end{array}$ & $\begin{array}{l}\text { Giving information } \\
\text { about technology } \\
\text { and society }\end{array}$ & $\begin{array}{l}\text { Giving information } \\
\text { about technology } \\
\text { and society }\end{array}$ \\
\hline $\begin{array}{l}\text { Technology-Science- } \\
\text { Society }\end{array}$ & $\begin{array}{l}\text { The effect of technology } \\
\text { use on socialization }\end{array}$ & $\begin{array}{l}1 \text { class } \\
\text { hour }\end{array}$ & $\begin{array}{l}\text { Playing the } \\
\text { competition called } \\
\text { 'I will shoot a } \\
\text { basket and get the } \\
\text { score/ Evaluating } \\
\text { the process of } \\
\text { competition }\end{array}$ & $\begin{array}{l}\text { Question-answer, } \\
\text { Evaluating } \\
\text { information through } \\
\text { activities like a } \\
\text { worksheet }\end{array}$ \\
\hline $\begin{array}{l}\text { Technology-Science- } \\
\text { Society }\end{array}$ & $\begin{array}{l}\text { Paying attention to using } \\
\text { virtual environments } \\
\text { safely }\end{array}$ & $\begin{array}{l}2 \text { class } \\
\text { hours }\end{array}$ & $\begin{array}{l}\text { Giving information } \\
\text { about accurate and } \\
\text { reliable information }\end{array}$ & $\begin{array}{l}\text { Giving information } \\
\text { about accurate and } \\
\text { reliable information }\end{array}$ \\
\hline $\begin{array}{l}\text { Technology-Science- } \\
\text { Society }\end{array}$ & $\begin{array}{l}\text { Paying attention to using } \\
\text { virtual environments } \\
\text { safely }\end{array}$ & $\begin{array}{l}1 \text { class } \\
\text { hour }\end{array}$ & $\begin{array}{l}\text { Playing the } \\
\text { gamification called } \\
\text { 'Crazy Racket/ }\end{array}$ & $\begin{array}{l}\text { Evaluation of } \\
\text { information by } \\
\text { working paper and }\end{array}$ \\
\hline
\end{tabular}




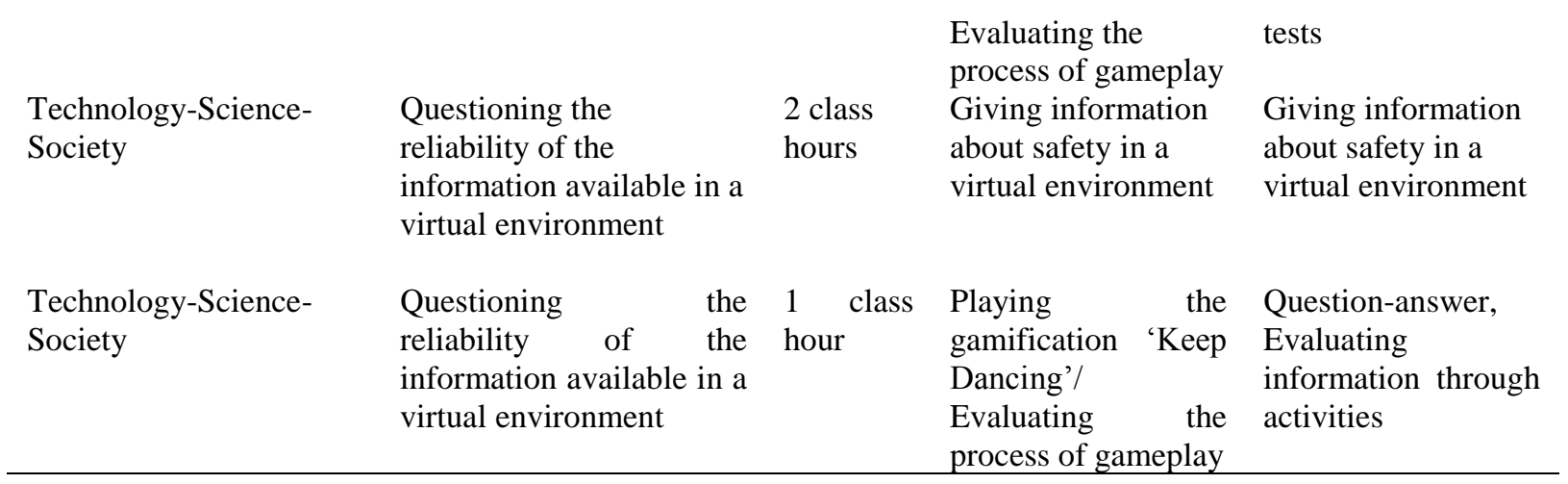

\subsection{Data Analysis}

The scores obtained based on the Reponses to the 5-point Likert-type scales as the data collection tools used in the research are not considered as standard due to the varying item numbers in subfactors. Therefore, converting the raw scores into standard scores with a minimum of 20 and a maximum of 100 was considered to be appropriate. Initially, whether the data was normally distributed was checked in order to see if it is possible carry out parametric analysis of the data collected. The analysis done related to this is summarized in Table 5.

Table 5. Normality Analysis

\begin{tabular}{|c|c|c|c|c|c|c|c|}
\hline & & $\mathrm{X}$ & ss & Skewness & Kurtosis & $\begin{array}{l}\text { Shapiro- } \\
\text { Wilk }\end{array}$ & $\mathrm{p}$ \\
\hline \multirow{8}{*}{ 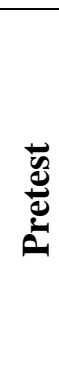 } & Love & 4,2 & 6,89 & $-0,960$ & 0,778 & 0,929 & 0,002 \\
\hline & Benefit & 2,4 & 1,75 & $-1,485$ & 1,972 & 0,694 & 0,000 \\
\hline & Interest & 5,1 & 5,23 & $-1,310$ & 1,352 & 0,851 & 0,000 \\
\hline & Motivation & 4,1 & 5,05 & $-1,166$ & 0,929 & 0,870 & 0,000 \\
\hline & Trust & 6,75 & 6,07 & $-1,446$ & 1,604 & 0,804 & 0,000 \\
\hline & Attitude Total & 9,7 & 2,31 & $-0,974$ & 0,462 & 0,912 & 0,000 \\
\hline & Cooperativeness & 7,41 & 5,56 & $-0,722$ & 0,022 & 0,948 & 0,012 \\
\hline & Academic Success & 1,43 & 0,58 & $-0,973$ & 0,601 & 0,921 & 0,001 \\
\hline \multirow{8}{*}{ 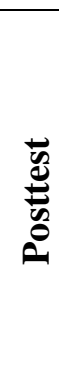 } & Love & 1,2 & 3,07 & $-1,414$ & 1,972 & 0,881 & 0,000 \\
\hline & Benefit & 6,2 & 5,63 & $-1,975$ & 1,756 & 0,465 & 0,000 \\
\hline & Interest & 0,2 & 1,31 & $-1,996$ & 1,998 & 0,670 & 0,000 \\
\hline & Motivation & 0,13 & 0,75 & $-1,098$ & 1,041 & 0,851 & 0,000 \\
\hline & Trust & 0,25 & 0,03 & $-1,711$ & 1,992 & 0,718 & 0,000 \\
\hline & Attitude Total & 8,27 & 0,35 & 1,983 & 1,991 & 0,817 & 0,000 \\
\hline & Cooperativeness & 0,4 & 5,28 & $-0,739$ & 0,716 & 0,956 & 0,029 \\
\hline & Academic Success & 3,58 & 8,5 & $-0,455$ & $-0,678$ & 0,946 & 0,010 \\
\hline
\end{tabular}

When the data in Table 5 obtained from the scales conducted as pretest and posttest is investigated, the Shapiro-Wilk analysis results of all the factors and total scores show a significant difference; in other words, it is observed that all the factors and total scores from the pretests and posttests are not normally distributed. On the other hand, it is also observed that Skewness and Kurtosis values are between 0,022 and 1,998. The data can be regarded as normally distributed if Skewness and Kurtosis values are between -1.5 and +1.5 according to Tabachnick \& Fidell (2013) and -2 and +2 according to George and Mallery (2010). In this sense, it was determined that the data obtained within the scope of the research was normally distributed and parametric analysis can be done on the data. Arithmetic average, standard deviation and t-test analysis were done on the data. For the analysis, $\mathrm{p}<0,05$ significance level 
was considered as enough.

\section{Findings}

Before the implementation, if the groups matched in terms of their attitude towards social studies course, cooperative learning skills and academic success was investigated in Table 6.

Table 6. Findings about the equivalence of groups before the implementation

\begin{tabular}{|c|c|c|c|c|c|c|c|}
\hline Variables & & $\mathbf{N}$ & $\overline{\mathbf{X}}$ & S.S & $\mathbf{t}$ & d & $\mathbf{p}$ \\
\hline \multirow{2}{*}{ Love } & Experiment & 31 & 73,5 & 18,6 & \multirow{2}{*}{0,321} & & \multirow{2}{*}{0,749} \\
\hline & Control & 29 & 74,9 & 15,1 & & & \\
\hline \multirow{2}{*}{ Benefit } & Experiment & 31 & 91,7 & 12,8 & \multirow{2}{*}{$-0,490$} & & \multirow{2}{*}{0,626} \\
\hline & Control & 29 & 93,2 & 10,7 & & & \\
\hline \multirow{2}{*}{ Interest } & Experiment & 31 & 84,1 & 17,5 & \multirow{2}{*}{$-0,490$} & & \multirow{2}{*}{0,626} \\
\hline & Control & 29 & 86,1 & 12,7 & & & \\
\hline \multirow{2}{*}{ Motivation } & Experiment & 31 & 84,1 & 15,4 & \multirow{2}{*}{0,027} & & \multirow{2}{*}{0,979} \\
\hline & Control & 29 & 84,2 & 15,1 & & & \\
\hline \multirow{2}{*}{ Trust } & Experiment & 31 & 85,8 & 17,1 & \multirow{2}{*}{0,467} & 58 & \multirow[t]{2}{*}{0,652} \\
\hline & Control & 29 & 87,8 & 15,1 & & & \\
\hline \multirow{2}{*}{ Attitude Total Score } & Experiment & 31 & 82,2 & 13,6 & \multirow{2}{*}{0,442} & & \multirow[t]{2}{*}{0,660} \\
\hline & Control & 29 & 83,7 & 10,9 & & & \\
\hline \multirow{2}{*}{ Cooperativeness } & Experiment & 31 & 68,5 & 16,7 & \multirow{2}{*}{1,553} & & 0,126 \\
\hline & Control & 29 & 74,6 & 13,9 & & & \\
\hline \multirow{2}{*}{ Academic Success } & Experiment & 31 & 64,1 & 23,7 & \multirow{2}{*}{1,059} & & \multirow[t]{2}{*}{0,294} \\
\hline & Control & 29 & 69,7 & 16,6 & & & \\
\hline
\end{tabular}

Table 6 shows that before the experimental implementation, there was not a significant difference between the students in experimental and control group in terms of their attitude towards social studies course $\left(\mathrm{t}_{(2-58)}=-0,442, \mathrm{p}>0,05\right)$, academic success $\left(\mathrm{t}_{(2-58)}=-1,059\right.$, $\mathrm{p}>0,05)$. In the light of this, it could be said that there is a match between the groups in terms of these qualities. However, when the averages are checked, it is observed that there are minor differences between experimental and control groups. To gain a better control over these small differences, the discrepancies between pretest and posttest were calculated in the analysis below and investigated.

Table 7 below summarizes the discrepancies between posttest-pretests which were done to see if there is a change in students' attitude towards social studies course, cooperative learning and social studies course itself as a result of the social studies course supported by the gamification activities conducted during the experimental period.

Table 7. The effect of gamification activities on social studies education

\begin{tabular}{|c|c|c|c|c|c|c|c|}
\hline Variables & & $\mathbf{N}$ & $\overline{\mathbf{X}}$ & S.S & $\mathbf{T}$ & sd & $\mathbf{p}$ \\
\hline \multirow{2}{*}{ Love } & Experiment & 31 & 17,5 & 14,3 & \multirow{2}{*}{3,646} & & \multirow{2}{*}{,001 } \\
\hline & Control & 29 & 2,8 & 16,8 & & & \\
\hline \multirow{2}{*}{ Benefit } & Experiment & 31 & 7,5 & 12,3 & \multirow{2}{*}{0,605} & & \multirow{2}{*}{0,114} \\
\hline & Control & 29 & 2,8 & 10,5 & & 58 & \\
\hline \multirow{2}{*}{ Interest } & Experiment & 31 & 13,4 & 14,4 & \multirow{2}{*}{3,054} & & \multirow{2}{*}{0,003} \\
\hline & Control & 29 & 2,3 & 13,6 & & & \\
\hline
\end{tabular}




\begin{tabular}{|c|c|c|c|c|c|c|}
\hline \multirow{2}{*}{ Motivation } & Experiment & 31 & 10,1 & 11,2 & \multirow{2}{*}{2,370} & \multirow{2}{*}{0,021} \\
\hline & Control & 29 & 1,4 & 16,6 & & \\
\hline \multirow{2}{*}{ Trust } & Experiment & 31 & 12,5 & 14,9 & \multirow{2}{*}{3,017} & \multirow[t]{2}{*}{0,004} \\
\hline & Control & 29 & 0,2 & 16,4 & & \\
\hline \multirow{2}{*}{ Attitude Total Score } & Experiment & 31 & 12,9 & 10,7 & \multirow{2}{*}{3,686} & \multirow[t]{2}{*}{0,001} \\
\hline & Control & 29 & 2,2 & 12,1 & & \\
\hline \multirow{2}{*}{ Cooperativeness } & Experiment & 31 & 6,0 & 17,1 & \multirow{2}{*}{1,952} & \multirow[t]{2}{*}{0,045} \\
\hline & Control & 29 & $-0,4$ & 9,6 & & \\
\hline \multirow{2}{*}{ Academic Success } & Experiment & 31 & 10,5 & 8,7 & \multirow{2}{*}{3,250} & \multirow[t]{2}{*}{0,002} \\
\hline & Control & 29 & 2,9 & 9,3 & & \\
\hline
\end{tabular}

When Table 7 is examined, it is observed that compared to the traditional method, social studies education supported by educational gamifications lead to a significant difference in students' attitude towards social studies course $\left(\mathrm{t}_{(2-58)}=3,686 ; \mathrm{p}<0,05\right)$. Similarly, when factors related to attitude are analyzed Love $\left(\mathrm{t}_{(2-58)}=3,646 ; \mathrm{p}<0,05\right)$, Interest $\left(\mathrm{t}_{(2-58)}=3,054 ; \mathrm{p}<0,05\right)$, Motivation $\quad\left(\mathrm{t}_{(2-58)}=2,370 ; \mathrm{p}<0,05\right)$ and Trust $\left(\mathrm{t}_{(2-58)}=3,017 ; \mathrm{p}<0,05\right)$ show significant differences. On the other hand, a significant difference is not observed in Benefit $\left(t_{(2-}\right.$ $\left.{ }_{58)}=1,605 ; \mathrm{p}>0,05\right)$ factor. The averages show that there is an improvement in favor of experimental group both in terms of total and factors. Based on this, it can be argued that compared to the traditional method, social studies course supported by educational gamifications significantly improve the attitudes toward social studies course except for the factor of Benefit.

It can be seen in Table 7 that compared to the traditional method, social studies education supported by educational gamification lead to a significant difference in students' academic success in social studies course $\left(\mathrm{t}_{(2-58)}=3,250 ; \mathrm{p}<0,05\right)$. The averages show that there is an improvement in favor of the experimental group. Based on this, it can be said that compared to the traditional method, social studies course supported by educational gamification significantly improve the students' academic success in social studies course.

\section{Discussion and Result}

The aim of this study is identifying the influence of gamification activities over the students' academic success in social studies course, their attitude towards the course and their cooperative learning skills. The study demonstrated that learning processes enriched by gamification activities contributed to student success, which is in line with the literature as well. For example, in the study done by Karabacak (1996), it was stated that the use of gamification activities at the final stage; that is, at the evaluation stage offers the students the opportunity to revise what they have learned. Besides, it was also indicated in the study that the use of gamification activities at the final stage facilitates the visual and verbal coding of the information in the long-term memory, which contributes to student success. Hanbab and Bektaş (2011) carried out a study with the aim of investigating the impact of gamification over success and revealed that games proved effective. In the literature, there are similar studies in different fields. To illustrate, in a study by Şenol (2007), games were integrated into vocabulary teaching and it was observed that they had a positive effect on student success. Apart from these, a study by Kaya (2007) demonstrated that gamification activities contributed to student success in foreign language teaching. The study focused on the effect of gamification as a technique on English course and the study put forward the positive 
influence of gamification over learning English. The fact that gamification is listed by MONE as one of the methods to be used in social studies teaching supports all these studies.

One of the subproblems of this is to determine the effect of gamification activities over the students' attitude towards social studies course. The study revealed significant discrepancies between the groups with the last attitude test regarding the factors love, interest, motivation and trust. For example, the study conducted by Can (2010) supports this finding. The study revealed that the students in the experimental group showed more interest to the course whereas the students in the control group did not show the same level of interest, felt bored and did not want to participate in the course. Among the responses that students gave, a student made a negative comment saying that the class was crowded, and this limited the chances of participating in the gamification. A study done by Polat (2014) showed that the gamification activities used in English language teaching had a positive effect on the students' attitude. Another study, which was carried out Gibson et al. (2015), revealed that gamification and various rewards given to the students at the end of the games reinforced learning and promoted success. However, there are also studies available in the literature demonstrating the negative effect of gamification over the students' attitude and success. For example, a study done by Hanus and Fox (2015) showed that in classes where teaching is done through gamification, it was observed that student motivation dropped in time and students started to receive lower grades. Furthermore, it was also seen that students put pressure on each other within their group. In general, considering the data of this study and the effects of gamification method over student interest, attitude and motivation stated in the literature, it would be fair to say that there are more studies showing the positive effects of gamification. Several studies involving the implementation of gamification method in the courses have been done in various fields and the results obtained are similar to the ones in this study. Among these studies, the studies done by Bayat Kılıçarlan and Şentürk (2014), Karamustafaoğlu and Kaya (2013), Muntean (2011) can be shown as examples.

The effect of gamification activities on the cooperative learning skills of the students is another subproblem of this study. The results of the study showed that the experimental implementation had a positive influence over the students' attitude towards cooperative learning. Having a closer look into the studies done by Miller (1989), Johnson, Johnson and Holubec, (1994) and Gömleksiz (1993), it was seen that the bond between the members in cooperative learning groups has improved. In such a group, a student can achieve success only if the team members succeed. It is stated that target, reward and a sense of duty are all part of this bond. The same studies indicate that in traditional learning environments, group members were not observed to have a bond with each other. It was argued that in cooperative learning environments, group members carried each other's responsibility to learn; in traditional learning environments; however, group members assumed their own responsibility to learn as an individual. The results of the study demonstrate that compared to competition and individual study, cooperative learning has positive effects on various aspects of learning. Johnson \& Johnson (1996) emphasize in their study that success in cooperative learning groups highly depends on that of all the members within that group and striving to attain a common aim is likely to take the students to a level of success higher than the one they can achieve on their own.

In the light of the findings obtained as a result of this study, which focused on integrating gamification method into social studies course, the following suggestions can be made: 
- Compared to traditional method, gamification elements have a positive influence over student success. Therefore, teachers of both social studies course and other courses can be recommended to use gamification method.

- It was observed that gamification method improved student attitude towards the course. That's why, this method can be utilized to involve the students who are not interested in the course.

- In social studies program, gamification method can be suggested to ensure the active participation of the students, especially while covering abstract subjects.

- It can be suggested to present students a variety of gamification by developing several tools related to the games like game cards, crosswords and so on).

- Teachers of social studies courses or those of other courses can be offered opportunities for gamification courses and implementations.

\section{Acknowledgments}

This study is based on the non-thesis master project written by Çilem Öztürk under the supervision of Özgen Korkmaz.

\section{References}

Acar, R. (2003). Issues encountered while delivering the content of social studies course and solutions suggested to address them. Unpublished Master's Thesis. Eskisehir: A.U. Institute of Social Sciences.

Açıkgöz, K.U. (2003). Effective Learning and Teaching, İzmir: World of Education Publishers.

Alkan, C. \& Kurt M. (1998). Special Teaching Methods. Ankara: Anı Publishers

Arslantaş, S. (2006). Investigation of the issues encountered in grades 6 and 7 th during the implementations of social studies course program from teachers' perspectives. (The example of Malatya province). Unpublished Master's Thesis. Malatya: F.U. Institute of Social Sciences.

Aycan S., Türkoğuz, Ş., Arı, E \& Kaynar, Ü. (2002). Teaching periodic table and elements through bingo technique and identifying the permanence in memory. Congress of National Physical Sciences and Mathematics Education, Proceedings Book. METU, Ankara.

Barbara, L. (2002). Building social studies resources in the constructivist classroom. Business Source Complete, Library Talk, 15(1), 14-15.

Bayat, S., Kılıçarslan, H., \& Şentürk, Ş. (2014). Investigating the effect of educational games in science and tehnology course on the academic success of students at grade 7. Abant Izzet Baysal University Faculty of Education Journal, 14(2), 204-216.

Bayram, E., Özgül, E., Kaplan, G., Ünal, H. A., Yapağılı, H., Demir, K., Morgül, M., Uğurlu, N., Tantoğlu, S., Özünel, Ş., \& Ömür, Ü. (1999). Drama at Primary School. Ankara: MEB Publishers.

Binbaşığlu, C.(1981). Special Teaching Methods. Ankara: Binbaşığlu Yayınevi.

Brufee, K. (1993). Collaborative Learning: Higher Education, Interdependence and the Authority of Knowledge, Baltimore, Md: Johns Hopkins University Press

Can, İ. (2010). The effect of teaching sciences through games at primary education on the attitude and success of grade 8 students for the unit about the structure and features of matter. Unpublished Master's Thesis. Gazi University, Institute of Educational Sciences, Ankara. 
Canbay, İ. (2012). Investigation of educational games in Mathematics on the pre-regulatory learning strategies, motivational beliefs, and academic success of grade 7 students. Master's Thesis, Marmara University, Institute of Educational Sciences, İstanbul.

Chen, C. (2003). A Constructivist Approach to Teaching; Implications in Teaching Computer Networking. Information Technology, Learning and Performance Journal, 21(2), 17-27.

Coşkun, H. (2012). The effect of teaching sciences through games with scientific stories on students' academic success. Master's Thesis, Erciyes University, Institute of Educational Sciences, Kayseri.

Coşkun, H., Kariper, A. \& Akarsu, B. (2012). The effect of educational games involving scientific stories on the academic success of the students in science and technology course. Ahi Evran University Kırşehir Faculty of Education Journal, 13(1), 93-109.

Demir, M. (2012). The effect of teaching the systems of human body unit in grade 7 with game-based learning on students' academic success and their attitude towards science and technology course. 10. A conference paper presented in National Science and Mathematics Education Congress. Niğde.

EL-Deghaidy, H., \& Nouby, A. (2008). Effectiveness of a blended e-learning cooperative approach in an Egyptian teacher education programme. Computers \& Education, 51(3), 988-1006.

George, D., \& Mallery, M. (2010). SPSS for Windows Step by Step: A Simple Guide and Reference, 17.0 update (10. ed.) Boston: Pearson

Gibson, D., Ostashewski, N., Flintoff, K., Grant, S., \& Knight, E. (2015). Digital badges in education. Education and Information Technologies, 20, 403-410.

Gömleksiz, M. (1993). The effect of cooperative learning and traditional learning on democratic attitudes and gain. Unpublished Doctoral Thesis, Çukurova University.

Gömleksiz, M. N., Kan, A.Ü. (2013). A Study of Validity and Reliability of an Attitude Scale on Social Studies Course. Frrat University Journal of Social Science 23(2), 139-148,

Güler, T. D. (2011). The effect of teaching 'cell and its organelles' subject in grade 6 with educational game method on the students' academic success. Master's Thesis. Atatürk University, Institute of Educational Sciences, Erzurum.

Hanus, M. D., \& Fox, J. (2015). Assessing the effects of gamification in the classroom: A longitudinal study on intrinsic motivation, social comparison, satisfaction, effort, and academic performance. Computers \& Education, 80, 52-161

Hazne, M., \& Berger, R. (2007). Cooperative learning, motivational effects, and student characteristics: An experimental study comparing cooperative learning and direct instruction in 12th grade physics classes. Learning and Instruction, 17(1), 29-41.

Hennessy, D., \& Evans, R. (2006). Small-group learning in the community college classroom. The Community College Enterprise,12(1), 93-110.

Johnson, D.W., Johnson, R.T. \& Holubec, EJ. (1994). The Nuts \& Bolts of Cooperative Learning. Edina: Interaction Book Company.

Johnson, D.W., \& Johnson, R.T. (1996). Meaningful and Managable Assessment Through Cooperative Learning. Edina. InteractionBook Company.

Jones, M. (2001). Game and child. Translated by Ayda Çayır. Kaknüs Publishers, İstanbul.

Karabacak, N. (1996). The effect of educational games on the achievement level of the students in social studies course. Unpublished master's thesis. Hacettepe University. Institute of Social Sciences. Ankara.

Karamustafaoğlu O., \& Kaya M. (2013). Teaching 'reflection and mirror' subject with educational games: Reflective subject sample. Research Based Activity Journal (RBAJ), 3(2), 4149. 
Kaya, Ü. Ü. (2007). The effect of game technique on the achievement level in primary school grade 1. Unpublished master's thesis. Kocatepe University, Afyonkarahisar.

Kisakürek, M. A. (1996). Social studies teaching with special teaching methods. A.Ö.F. Publishers, 221:30-34

Kiper, A. (2016). Cooperative Learning Scale: Validity and Reliability Study. International Journal of Educational Research Review. 1(2): 42-48.

Kramer, W. (2000, December). What is a Game? The Games Journal. Retrieved from: http://www.thegamesjournal.com/articles/WhatIsaGame.shtml

Kula, A., \& Erdem, M. (2005). The effect of educational computer games on the improvement of basic arithmetic skills. Hacettepe University, Journal of Education, 29:127-136.

Maroney, K. (2001). My entire waking life. The Games Journal. Retrieved from: http://www.thegamesjournal.com/articles/MyEntireWakingLife.shtml

MONE, (2018). Social Studies http://mufredat.meb.gov.tr/Dosyalar/201812103847686-

SOSYAL\%20B\%C4\%B0LG\%C4\%B0LER\%20\%C3\%96\%C4\%9ERET\%C4\%B0M \%20PROGRAMI\%20.pdf

Miller, A. K. (1989). Enhancing Early Childhood Mainstreaming Through Cooperative Learning: A Brief Literature Review. Child Study Journal, 19: 4, 285-291.

Muntean, C. I. (2011). Raising engagement in e-learning through gamification. Paper presented at Proceedings of the $6^{\text {th }}$ International Conference on Virtual Learning ICVL, University of Bucharest and "Babeş Bolyai" University of Cluj-Napoca. http://icvl.eu/2011/disc/icvl/documente/pdf/met/ICVL_ModelsAndMethodologies_pa pe r42.pdf

Öztemiz, S. \& Önal, H. İ. (2013). Opinions of teachers on helping students gain literacy skills at primary school through game technique: Ankara Beytepe Primary School Example. Bitlis Eren University Institute of Social Sciences Journal, 2(1), 70-85.

Polat, Y. (2014). A case study: Gamification method and its effect on students in English course (Unpublished master's thesis). Çăg University, Mersin.

Prensky, M. (2001). Digital natives, digital immigrants' part 1. On the horizon, 9(5): 1-6.

Prensky, M. (2002). The motivation of gameplay: The real twenty-first century learning revolution. On the Horizon, 10(1): 5-1.

Saracaloğlu, A. S., \& Aldan Karademir, Ç. (2009). The effect of educational game-based science and technology instruction on student success. VIII. National School Teachers Education Symposium, Proceedings Book. 21-23 May, Osmangazi University: Eskişehir, 1098-1107.

Sar1, A., \& Altun, T. (2016). The investigation of student opinions on computer courses with gamification method. Turkish Journal of Computer and Mathematics Education,7(3), 553-577.

Sönmez, V. (1996). Social Studies Instruction (Extended $2^{\text {nd }}$ Edition) Ankara: Pegem Publishers.

Şenol, M. (2007). Vocabulary instruction for primary school students through games. Unpublished master's thesis. Selçuk University, Konya.

Tabachnick, B.G., \& and Fidell L.S. (2013). Using Multivariate Statistics (sixth ed.). Pearson, Boston

Tannenberg, J. (1995). Using Cooperative Learning in The Undergraduate Computer Science Classroom, Proceedings of The Midwest Smail College Computing Conference, Available http://Phoenix.Isub.Edu/Jost1lCooplPapers/Mwscc95.Html

Poyrazoğlu O. N. (1987). Social Studies Instruction in Secondary Education Institutions and its Problems. Ankara: Türk Eğitim Derneği Yayınları 
Uberman, A. (1998). The use of games for vocabulary presentation and revision, Forum Online. 36(1), 20.

Uzun, N. (2012). A sample of active learning application in science education: The thema "cell" with educational games. Procedia Social and Behavioral Sciences,46, 2932 2936

Ülküdür, M. A. (2016). The effect of project-based and game-based educational activities on students' academic success, attitude and motivation. Master's Thesis, Amasya University, Institute of Science, Amasya.

Varışoğlu, B., Şeref, İ., Gedik, M., \& Yılmaz, İ. (2013). The attitude scale on the educational games played in Turkish course: Validity and reliability study. Adiyaman University Institute of Social Sciences Journal Turkish Education and Training Special Volume, 6(11), 1059-1081

Yurt E. (2007). Science instruction through educational game technique and its role in new primary education curriculum. (Muğla Province Example). Unpublished Master's Thesis, Muğla University, Institute of Science, Muğla. 